\title{
The Expression Pattern of the Transcription Factor Phox2 Delineates Synaptic Pathways of the Autonomic Nervous System
}

\author{
Marie-Catherine Tiveron, Marie-Rose Hirsch, and Jean-François Brunet \\ Laboratoire de Génétique et Physiologie du Développement, Institut de Biologie du Développement de Marseille, Centre \\ National de la Recherche Scientifique-Institut National de la Santé et de la Recherche Médicale-Université de la \\ Méditerranée, Luminy Case 907, 13288 Marseille Cedex 09, France
}

\begin{abstract}
Many transcription factors, and most prominently among them, homeodomain proteins, are expressed in specific groups of cells in the developing nervous system in patterns that suggest their involvement in neural fate determination. How various aspects of neural identity are controlled by such transcription factors, or sets of them, is still mostly unknown. It has been shown previously that Phox2 is such a homeodomain protein, expressed exclusively in differentiated groups of neurons or their precursors, and that its expression correlated with that of the noradrenaline synthesis enzyme dopamine- $\beta$-hydroxylase. Here we confirm this striking correlation at the single-cell level
\end{abstract}

with the use of an anti-Phox2 antibody. Moreover, we uncover a second, nonmutually exclusive correlative clue to the Phox2 expression pattern: a high proportion of Phox2-expressing cells are involved in, or located in areas involved in, synaptic circuits, i.e., that of the medullary control reflexes of autonomic functions. This suggests that Phox 2 could be involved in the establishment of these circuits.

Key words: homeodomain proteins; autonomic nervous system; synapse; neurotransmitter; dopamine- $\beta$-hydroxylase; choline acetyltransferase; sympathetic system; parasympathetic system
The mechanisms by which individual neurons are assigned their fates remain a central problem in developmental neurobiology. Genetic and molecular studies in Drosophila and in Caenorhabditis elegans have defined cascades of transcription factors that progressively commit neuronal precursors to a particular fate (for reviews, see Sternberg et al., 1992; Ghysen and DamblyChaudière, 1993). In vertebrates, many transcription factors, and among them many homeoproteins, are expressed in the developing nervous system of vertebrates in spatiotemporal patterns that suggest roles in the terminal differentiation of various classes of neurons. In a few cases, their requirement for the proper differentiation of neuronal populations has been demonstrated by gene inactivation, which results in early neuronal degeneration (Guillemot et al., 1993; Nakai et al., 1995; Schoneman et al., 1995; Erkman et al., 1996; Pfaff et al., 1996). No bona fide phenotypic switch has yet been reported in these loss-of-function phenotypes, like those described in invertebrates, (Bodmer et al., 1987; Tetsuya et al., 1991; Jin et al., 1994; Miller and Niemeyer, 1995; Walthall and Plunkett, 1995), and it remains a major challenge to sort out what part of the differentiation pathway (morphology, connectivity, transmitter phenotype, etc.) is under the control of what transcription factor, or what could be called the "transcriptional logic" of neural fate determination. Nevertheless, a few detailed expression studies have uncovered compelling correlations between transcription factor expression and aspects of neu-

\footnotetext{
Received July 9, 1996; revised Sept. 4, 1996; accepted Sept. 9, 1996.
}

This work was supported by institutional grants from the Centre National de la Recherche Scientifique and by specific grants from the European Community (BMH4-CT95-0524), the Ministère de l'Education Nationale, de l'Enseignement Supérieur et de la Recherche (ACC-SV4), and the Association Française contre les Myopathies. We thank Drs. S. Pfaff and T. Jessell for the kind gift of the ChAT cDNA clone, Dr. A. Jean for helpful comments, and Dr. Christo Goridis for invaluable discussions throughout this work and critical reading of this manuscript.

Correspondence should be addressed to Jean-Francois Brunet, Institut de Biologie du Développement (IBDM), Luminy Case 907, 13288 Marseille Cedex 9, France.

Copyright (C) 1996 Society for Neuroscience $0270-6474 / 96 / 167649-12 \$ 05.00 / 0$ ronal identity. The expression of members of the LIM family of homeoproteins in the ventrolateral neural tube predicts, on a combinatorial mode, the identity of motoneuron pools as defined by their target specificity (Tsuchida et al., 1994). A similar combinatorial mechanism involving the POU family of homeodomain proteins has been proposed to control the organization in functional subdomains of the hypothalamus (Schoneman et al., 1995). During sympathetic ganglion development, Mash-1 seems to specify a general neuronal phenotype, whereas expression of Phox2 and GATA-2 seems to play a role in the expression of neurotransmitter phenotype (Groves et al., 1995).

We have been studying Phox2, a transcription factor with a homeodomain related to that of the Drosophila homeogene paired (Valarché et al., 1993). Like other vertebrate and invertebrate members of the same broad, paired-like family (Frantz et al., 1994; Jin et al., 1994; Simeone et al., 1994; Miller and Niemeyer, 1995; Saito et al., 1995), the mouse Phox2 gene is expressed exclusively in specific types of neuronal precursors or differentiated neurons. In a preliminary survey of Phox2 expression sites during embryogenesis (Valarché et al., 1993), we suggested a correlation with sites of transient or permanent expression of the noradrenaline synthesis enzyme dopamine- $\beta$-hydroxylase (DBH); however, the method of localization, radioactive in situ hybridization, did not allow us to identify the great majority of Phox2positive cells in the CNS. Here we use single- and doublelocalization methods with single-cell resolution to show that all CNS noradrenergic and adrenergic neurons and their precursors express Phox2. Identification of these and other sites of Phox2 expression in the brain stem revealed another striking correlation, i.e., with synaptic pathways of the autonomic nervous system. Therefore, Phox 2 provides the intriguing and unprecedented example, with the possible exception of DRG-11, another member of the same class of homeoproteins (Saito et al., 1995), of a 

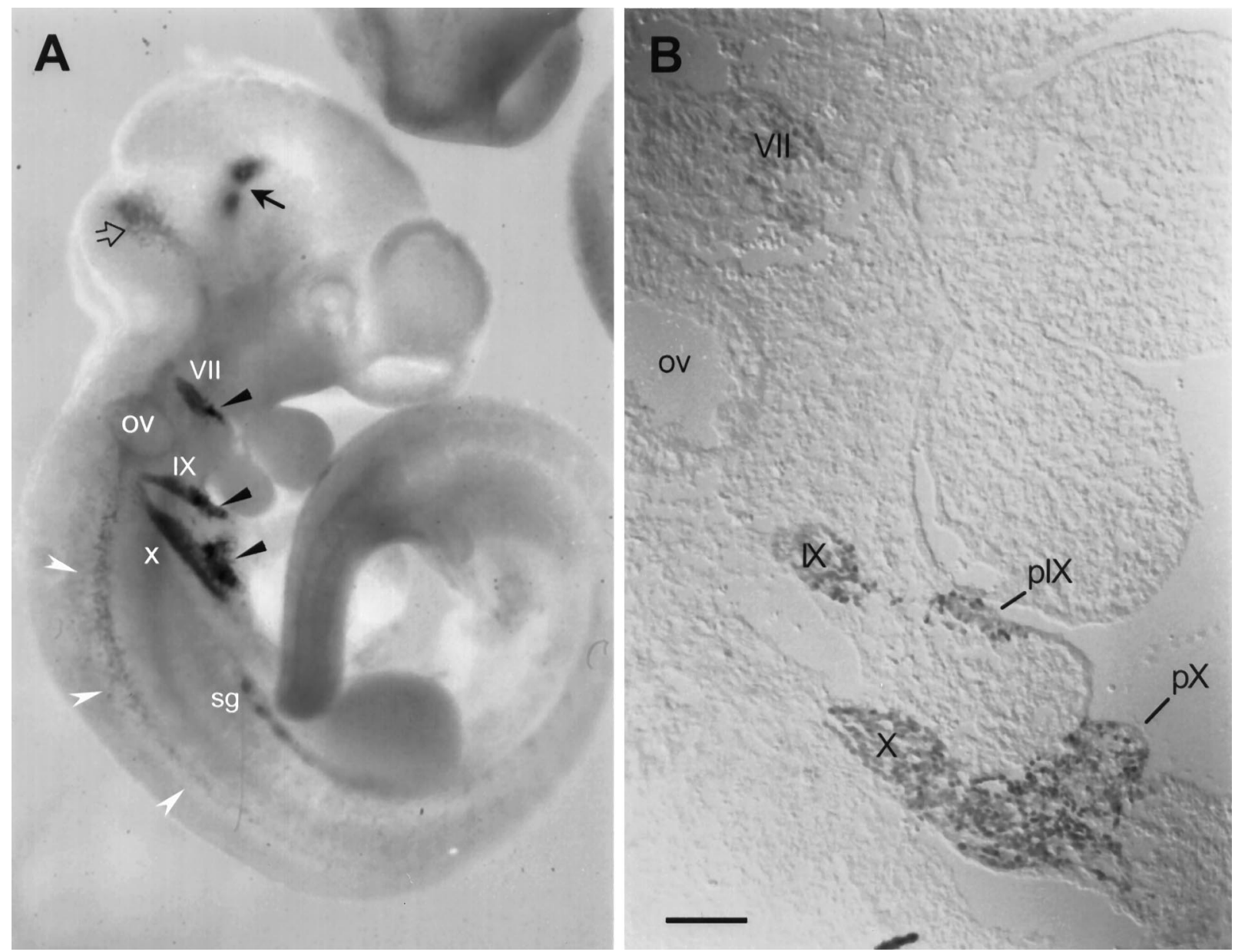

Figure 1. Phox2 expression at E10.5. A, Whole-mount preparation of an E10.5 mouse embryo hybridized with a Phox2 probe. Phox2 is strongly expressed in the distal part of the VIIth $(V I I)$, IXth $(I X)$, and Xth $(X)$ cranial ganglia and in their corresponding epibranchial placodes, which appear as darker patches (black arrowheads). Phox2 expression is just starting in the primordia of the sympathetic chain ( $s g$ ). In the CNS, staining can be seen in two patches in the ventral basal plate at the met-mesencephalic border (black arrow), in the lateral part of the first rhombomere (open arrow), where the anlage of the locus coeruleus lies, and more caudally in the ventrolateral hindbrain and rostral spinal cord (white arrowheads). ov, Otic vesicle. B, Immunostaining of a parasagittal section at E10.5 with anti-Phox2 antibody. Nuclear Phox2 expression is detectable in the aggregating anlagen of the VIIth (VII), IXth $(I X)$, and Xth $(X)$ cranial ganglia as well as in the second and third ectodermal placodes $(p I X$ and $p X)$ and the delaminating neuroblasts. The placode of the VIIth ganglion is no longer visible at that stage. Note that there is no discrepancy between the pattern of mRNA and protein expression. The apparent faintness of the signal in the VIIth ganglion is a photography artifact attributable to Nomarski optics. Scale bar (shown in $B$ ), $110 \mu \mathrm{m}$.

transcription factor whose expression domains correlate with functionally integrated neuronal populations.

\section{MATERIALS AND METHODS}

\section{Animals}

Swiss mice were mated at night. Females were checked in the morning for the presence of a vaginal plug; this corresponded to the gestational day 0.5 (E0.5). Pregnant animals were killed at E10.5, E11.5, and E13.5. Embryos were dissected from the embryonic annexes and fixed overnight in $4 \%$ paraformaldehyde in PBS.

Animals at postnatal day 12 (P12) were anesthetized deeply and perfused for $\sim 10$ min with $4 \%$ paraformaldehyde in PBS. Brains and spinal cords were dissected out and fixed further by immersion in the same fixative overnight.

\section{Production of an anti-Phox 2 antiserum}

Antibodies were raised against a BSA-coupled 15 amino acid-peptide (YFHRKPGPALKTNLF) corresponding to the $\mathrm{C}$ terminus of the Phox2 protein with an added N-terminal tyrosine. The specificity of the antiserum was tested on Western blot. A recombinant Phox 2 protein produced in bacteria was recognized by the antiserum. Similarly, a band was specifically detected in rhombocervical extracts of E10.5 embryos and in protein extracts of the neuroblastoma cell line N2a, from which Phox2 was cloned, but not in fibroblasts (not shown). On embryo sections, the expression pattern of the protein found in immunohistochemistry corresponded perfectly to the expression domains first observed by radioactive in situ hybridization (Valarché et al., 1993). Preimmune serum did not give any signal on Western blot or tissue sections. Furthermore, no staining could be detected in homozygote Phox $2^{-1-}$ mice generated by homologous recombination (X. Morin and M. C. Tiveron, unpublished observations).

\section{Probes for in situ hybridization}

Antisense digoxygenin (DIG)-labeled riboprobes were generated using a Boehringer transcription kit, following the manufacturer's instructions. The ChAT probe was synthesized from a rat cDNA clone kindly provided by Drs. S. Pfaff and T. Jessell. The mouse DBH probe was synthesized from a subcloned RT-PCR fragment amplified from the neuroblastoma cell line N2a and corresponding to most of the coding sequence. The Phox 2 probe was synthesized from the pKS903-SSN clone corresponding to the noncoding $3^{\prime}$ end of the mRNA.

\section{Whole-mount in situ hybridization of embryos}

Fixed embryos were treated for in situ hybridization as described in Wilkinson (1992). 

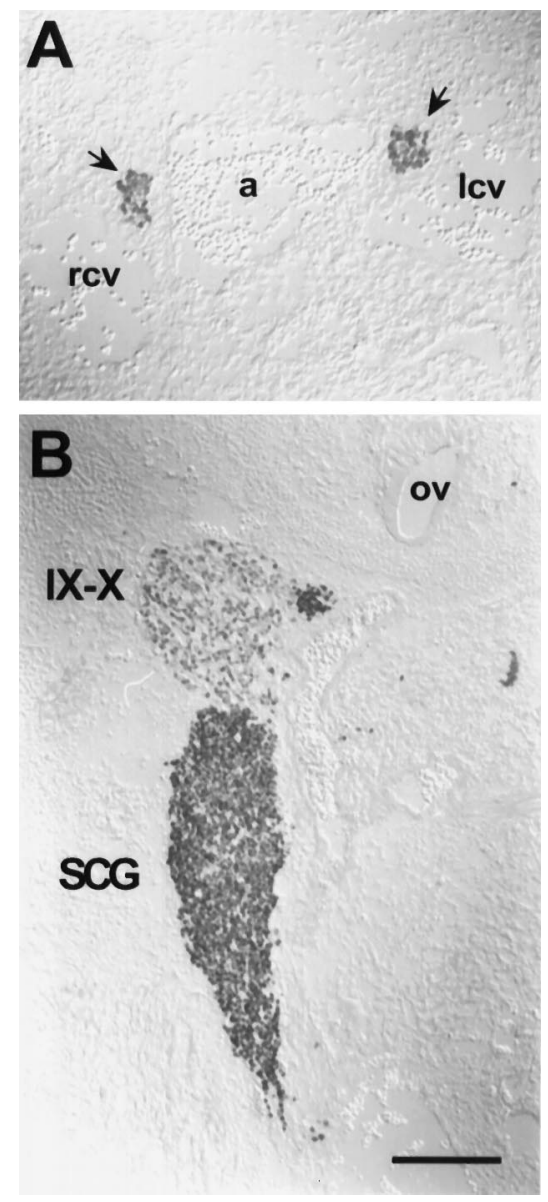

Figure 2. Phox 2 expression in the developing sympathetic nervous system. $A$, Immunostaining of a transverse section at E10.5. Phox2-positive neurons (arrows) aggregate on both sides of the dorsal aorta (a), dorsally to the cardinal veins ( $r c v$, right cardinal vein; $l c v$, left cardinal vein), to form the primordia of the sympathetic chain. $B$, Sagittal section at E13.5. Phox2 is highly expressed in all cells of the superior cervical ganglion $(S C G)$, whereas the expression in the distal IX-Xth cranial ganglionic complex $(I X-X)$ is now ebbing. $o v$, Otic vesicle. Scale bar: $A, 15 \mathrm{O} \mu \mathrm{m} ; B$, $180 \mu \mathrm{m}$.

\section{Combined nonradioactive in situ hybridization and immunohistochemistry on cryosections}

The method for in situ hybridization was adapted from Shaeren-Wiemers and Gerfin-Moser (1993).

Pretreatments of tissue sections. Fixed tissues or embryos were cryoprotected overnight in PBS with 15\% sucrose, and then embedded in OCT (Tissue-Tek, Miles, Elkhart, IN) and frozen on dry ice. Cryostat sections (10-14 $\mu \mathrm{m}$ for embryos and $10 \mu \mathrm{m}$ for brain and spinal cord) were thaw-mounted on Superfrost slides (Menzel-Gläser), left to dry at room temperature (RT), and stored at $-80^{\circ} \mathrm{C}$. Thawed sections were washed briefly with PBS, treated three $\times 10 \mathrm{~min}$ in RIPA buffer $(150 \mathrm{~mm} \mathrm{NaCl}$, $1 \%$ NP- $40,0.5 \%$ Na deoxycholate, $0.1 \%$ SDS, 1 mm EDTA, $50 \mathrm{~mm}$ Tris, $\mathrm{pH} 8.0$ ), postfixed in $4 \%$ paraformaldehyde for $15 \mathrm{~min}$ at RT, and washed three $\times 5$ min with PBS. Endogenous peroxydases were inactivated by a 30 min incubation with $0.5 \% \mathrm{H}_{2} \mathrm{O}_{2}$ in methanol followed by three $\times 5 \mathrm{~min}$ washes in PBS. The slides were then transferred in $100 \mathrm{~mm}$ triethanolamine, $\mathrm{pH} 8.0$, acetylated for $15 \mathrm{~min}$ at RT by adding dropwise acetic anhydride ( $0.25 \%$ final concentration) while being rocked, and washed again three $\times 5$ min in PBS-T (PBS, $0.05 \%$ Tween).

Prehybridization, hybridization, and posthybridization. The slides were prehybridized briefly with $500 \mu \mathrm{l}$ of hybridization solution (50\% formamide, $5 \times$ SSC, $5 \times$ Denhardt's, $500 \mu \mathrm{g} / \mathrm{ml}$ herring sperm DNA, 250 $\mu \mathrm{g} / \mathrm{ml}$ yeast RNA) and hybridized overnight at $70^{\circ} \mathrm{C}$ with the same solution in the presence of the heat-denatured DIG-labeled RNA probes. The following day, slides were placed in $5 \times \mathrm{SSC}$ at $70^{\circ} \mathrm{C}$ until coverslips

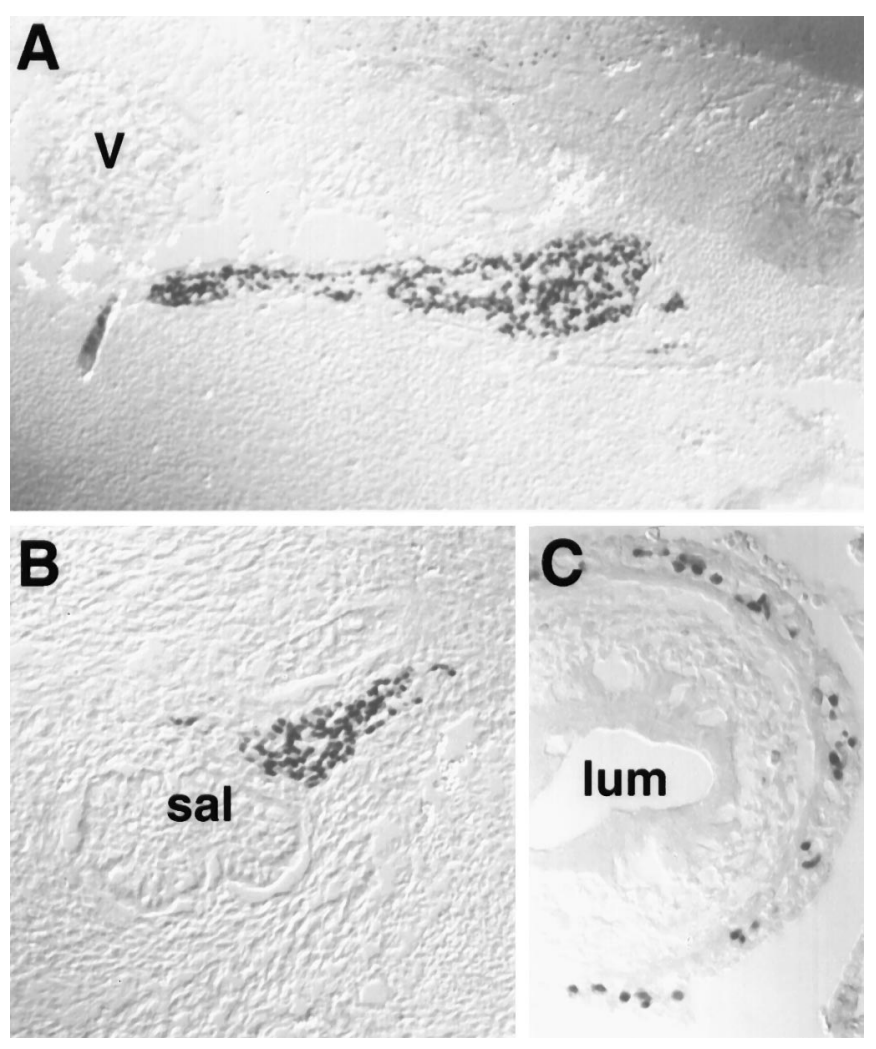

Figure 3. Phox 2 expression in the parasympathetic and enteric nervous systems at E13.5. $A$, The sphenopalatine ganglion, lying rostral to the trigeminal ganglion $(V)$, and $B$, a submandibular ganglion in the proximity of a salivary gland $(\mathrm{sal})$, are $\mathrm{Phox} 2^{+} . C$, $\mathrm{Phox} 2^{+}$neurons in the myenteric plexus in a transverse section of the gut. Half a day earlier, all parasympathetic and myenteric Phox $2^{+}$neurons were still expressing low levels of DBH (not shown). lum, Lumen of the gut.

slid off and then washed twice in $0.2 \times \mathrm{SSC}$ for $60 \mathrm{~min}$ at $70^{\circ} \mathrm{C}$ and finally in $0.2 \times \mathrm{SSC}$ at RT for $5 \mathrm{~min}$.

Immunological detection of DIG labeling. Slides were washed with buffer 1 (100 mM maleic acid, $\mathrm{pH} 7.5,150 \mathrm{~mm} \mathrm{NaCl}, 0.05 \%$ Tween 20 ), blocked for $30 \mathrm{~min}$ in buffer $2(1 \%$ heat-inactivated sheep serum in buffer 1), incubated for $1 \mathrm{hr}$ at RT with alkaline phosphatase-coupled anti-DIG antibody (Boehringer Mannheim, Indianapolis, IN) diluted 1:500 in buffer 2, rinsed twice for $5 \mathrm{~min}$ with buffer 1, and equilibrated for $1 \mathrm{hr}$ in buffer 3 (100 mM Tris, pH 9.5, $100 \mathrm{~mm} \mathrm{NaCl}, 50 \mathrm{mM} \mathrm{MgCl}_{2}$ ) with $2 \mathrm{mM}$ Levamisol (Sigma, St. Louis, MO) to block endogenous phosphatase activity. The signal was visualized by a color reaction using $250 \mu \mathrm{l}$ of buffer $4[4.5 \mu \mathrm{l} / \mathrm{ml}$ NBT (4-nitroblue tetrazolium chloride, Boehringer Mannheim), $3.5 \mu \mathrm{l} / \mathrm{ml}$ BCIP (5-bromo-4-chloro-3-indoyl-phosphate, Boehringer Mannheim) in buffer 3 with $2 \mathrm{~mm}$ Levamisol]. The color reaction was allowed to develop in the dark at $4^{\circ} \mathrm{C}$ overnight and was stopped with PBS-T

Immunohistochemistry. After a 30 min blocking step with heatinactivated fetal calf serum (HI FCS), slides were incubated overnight at $4^{\circ} \mathrm{C}$ with anti-Phox 2 antibody (diluted 1:1000 in PBS-T, 5\% HI FCS) in a humidified chamber. After being washed three times for 5 min with PBS-T, 5\% HI FCS, they were incubated for $2 \mathrm{hr}$ at RT with the biotinylated anti-rabbit antibody from Vectastain ABC kit (Vector, Burlingame, CA). After three washes for $10 \mathrm{~min}$ with PBS, they were incubated for $1 \mathrm{hr}$ with the peroxydase-Vectastain $\mathrm{ABC}$ reagents (Vector) and then washed twice for $10 \mathrm{~min}$ in PBS and once with $120 \mathrm{~mm}$ Tris, $\mathrm{pH} 7.5$, for $5 \mathrm{~min}$. Color development was performed by using diaminobenzidine (Sigma). The sections were immersed in PBS to stop the reaction and then rinsed briefly in $\mathrm{H}_{2} \mathrm{O}$, dried, and mounted in Mowiol (Calbiochem, La Jolla, CA).

Sections used for immunohistochemistry alone were washed quickly in PBS and postfixed with $4 \%$ paraformaldehyde, washed three $\times 10 \mathrm{~min}$ with PBS, treated in methanol/ $0.5 \% \mathrm{H}_{2} \mathrm{O}_{2}$ as described above, and 


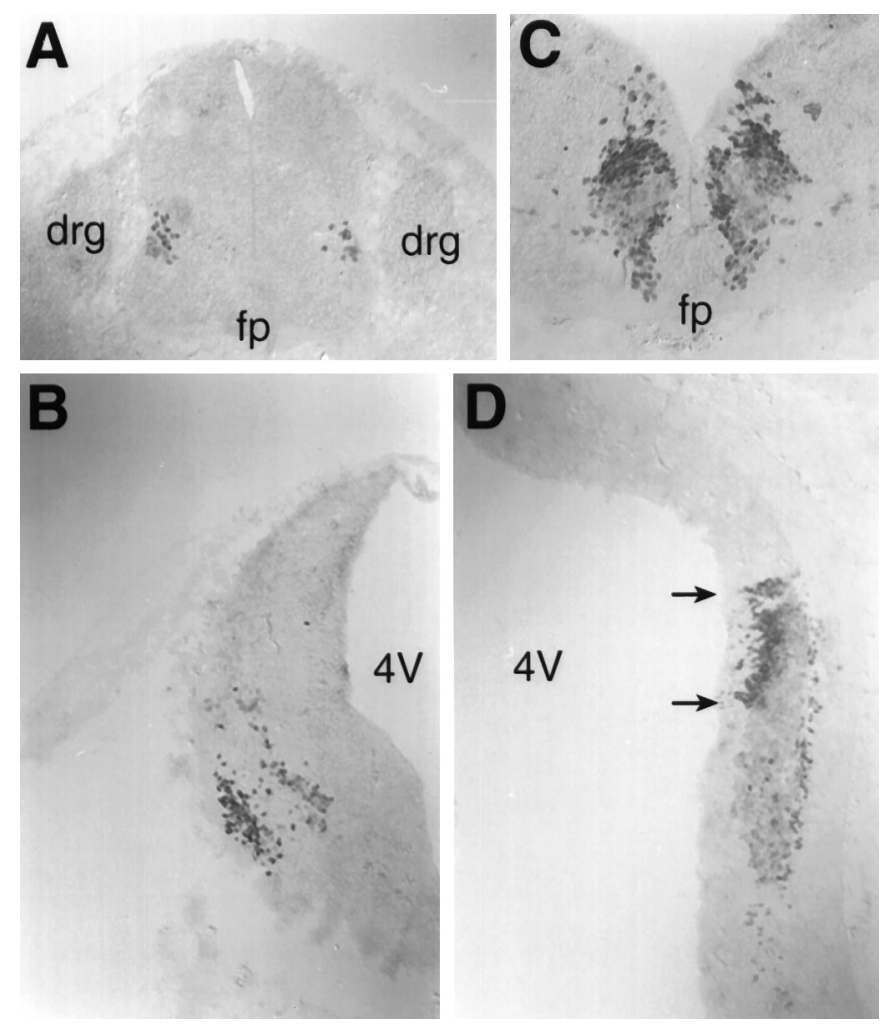

Figure 4. Phox 2 immunostaining of the CNS of E11.5 embryos. $A$, Transverse section through the neural tube at the thoracic level. A group of Phox $2^{+}$cells is visible in the lateral neural tube, just dorsal to the motoneuron columns. No double-labeling was detected with an Islet-1specific cRNA probe (not shown). This expression pattern was observed throughout cervical, thoracic, and lumbar levels. $B$, Left side of a coronal section through the caudal hindbrain. The lateral column of Phox $2^{+}$cells seen in $A$ is now broader and appears split into two layers. $C$, Coronal section through the hindbrain at the level of the fourth rhombomere. Phox2-positive cells are located in the mantle layer of the basal plate. The floor plate is free of signal, as is the proliferative layer, except for a few isolated cells that are probably postmitotic neurons migrating toward the mantle layer. Phox 2 high-expressing and low-expressing cells can be distinguished. This domain of Phox2 expression overlaps with an Islet-1expressing domain (not shown), presumably corresponding to the precursors of the facial nucleus motoneurons. $D$, Parasagittal section through the hindbrain. The arrows point out the boundaries of rhombomere 4. Note the sharp rostral limit of Phox2-expressing domain at the fourth-third inter-rhombomeric boundary; in fact, some cells can be found in the third rhombomere in another plane of section (not shown). The fourth rhombomeric expression domain continues caudally into the fifth, mostly in the form of low-expressing cells whose nuclei, at higher magnification, appear longitudinally oriented, suggesting a migratory behavior. $4 v$, 4 th ventricle; $d r g$, dorsal root ganglia; $f p$, floor plate.

washed again three $\times 10$ min in PBS. The blocking and following steps were performed as above.

\section{RESULTS}

In a previous study, we identified three broad domains of Phox2 expression in mouse embryos: some cranial ganglia, all autonomic ganglia, and several groups of neurons in the hindbrain and at the met-mesencephalic junction (Valarché et al., 1993). Here we used anti-Phox 2 antibodies (see Materials and Methods) to examine the early pattern of Phox 2 expression in these three territories with single-cell resolution. To identify neuronal types, we combined anti-Phox2 immunocytochemistry with in situ hybridization for $\mathrm{DBH}$ and choline acetyltransferase (ChAT). In addition, we analyzed Phox 2 expression in the postnatal mouse CNS, in which groups of neurons can be unambiguously assigned to anatomically identifiable nuclei.

\section{Embryonic patterns of Phox2 expression}

Peripheral nervous system

At E9.5 and until E10.5 (Fig. $1 \mathrm{~A}$ ) in whole-mount in situ hybridizations, a prominent expression domain of Phox 2 is represented by three patches at the level of the first, second, and third branchial clefts corresponding to the ectodermal placodes of the VIIth, IXth, and Xth cranial ganglia. These placodes have been shown in the chicken to give rise to the neuronal component of the distal VIIth, IXth, and Xth cranial ganglia, respectively (D'Amico-Martel and Noden, 1983). The signal extending toward the neural tube corresponds to neural progenitors in the process of delaminating from the placodes and to the forming ganglia, which are equally strongly labeled. An immunocytochemical localization of Phox 2 on parasagittally sectioned E10.5 embryos (Fig. 1B) showed the Phox2-positive second and third epibranchial placodes, the delaminating neuroblasts of the distal IXth and Xth ganglia, and the aggregating anlagen of these same ganglia. The distal VIIth, IXth, and Xth cranial ganglia were still labeled brightly at E11.5 (not shown) and until E13.5, at which stage the signal decreased (Fig. 2B). As reported previously (Valarché et al., 1993), the proximal ganglia of the same cranial nerves never expressed Phox2 (not shown). Neither was Phox2 expression detected in the Vth (Fig. $3 A$ ) or VIIIth cranial ganglia or in dorsal root ganglia.

At E10.5, Phox2 expression in the earliest primordia of the sympathetic chain was visible, both on whole-mount preparations (Fig. $1 A$ ) and on transversal sections, where two clusters of Phox2-positive cells frame the dorsal aorta from the lower cervical level to the lower trunk (Fig. $2 A$ ). Early appearance of Phox 2 in sympathetic neuron precursors has already been reported in chick embryos and correlated with the appearance of tyrosine hydroxylase message at approximately the same time (Ernsberger et al., 1995) and of tyrosine hydroxylase protein slightly later (Groves et al., 1995). At E13.5, all cells in all sympathoadrenal tissues were strongly labeled: the superior cervical ganglion (Fig. $2 B, S C G$ ), the stellate ganglion, the sympathetic trunk, the prevertebral and pelvic ganglia, and the adrenal medulla (not shown).

Phox2-positive cell clusters embedded within or in the proximity of peripheral organs corresponded to parasympathetic ganglia; in particular, we could identify the otic (not shown), sphenopalatine (Fig. $3 A$ ), submandibular (Fig. $3 B$ ), and paracardiac ganglia (not shown). They also expressed DBH at approximately E12.5E13 (not shown) and lost it as early as E13.5.

Finally, the myenteric plexus of the enteric nervous system was labeled as early as E10.5 and at least until E16.5 (Fig. 3C). It transiently expressed DBH until E13 (not shown), at which time the DBH signal dropped abruptly, in agreement with previous observations in the rat (Cochard et al., 1979; Baetge et al., 1990). Some authors (Baetge et al., 1990), however, have reported the persistence of a few $\mathrm{DBH}+$ neurons in the gut of the rat beyond E15 (equivalent to E13 in the mouse) and into adulthood. This discrepancy could be attributable to intrinsic differences between rat and mouse, or to a lesser sensitivity of our detection system. We have not examined the enteric nervous system at postnatal stages.

Therefore, all three divisions of the peripheral autonomic nervous system expressed Phox 2 at, or close to, the time of ganglion formation. Expression in the sensory components of the periph- 
eral nervous system is restricted to the subset of cranial ganglia derived from epibranchial placodes.

\section{CNS}

In whole-mount in situ hybridizations of E9.5 embryos, Phox2 was expressed in three domains of the CNS, that is, from caudal to rostral, as (1) a faint labeling in the ventrolateral hindbrain becoming fainter in the rostral spinal cord; (2) a group of scattered Phox2positive cells in the lateral aspect of the first rhombomere; and (3) two prominent patches of Phox 2 positivity in the ventral basal plate surrounding the met-mesencephalic junction. One day later (Fig. $1 A$ ), the met-mesencephalic patches were still prominent, the group of scattered cells in the rhombomere 1 had now elongated ventrocaudally, and a double column of cells was apparent in the lateral aspect of the rhombencephalon and spinal cord.

We examined this pattern in more detail at E11.5 on serial transverse, parasagittal, and coronal sections of the neural tube. At thoracic and cervical levels, there was a discrete column of Phox2-positive cells in the lateral neural tube, just dorsal to the motor columns (Fig. 4A). In combined Phox2 immunocytochemistry/Islet-1 in situ hybridization, these cells appeared Islet-1-negative and just dorsal to the Islet-1-positive motoneurons (not shown) (Ericson et al., 1992). This column thickened rostrally and at the level of the rhombencephalon became a broad, Phox2-positive region in the dorsal half of the basal plate, which in some sections appeared subdivided into a superficial and a deep layer (Fig. $4 B$ ). At the level of r5/r4, the deep layer extended toward the midline, merging with a discrete, densely packed group of Phox $2^{+}$cells in the ventral-most aspect of the basal plate (Fig. 4C,D). This population overlapped with an Islet-1-positive region (not shown) and contains the precursors of the motoneurons of the facial nucleus (Marìn and Puelles, 1995) (see below). The r3/r4 inter-rhombomeric boundary marked the rostral edge of the continuous myelencephalic domain of Phox2 expression (Fig. 4D).

Further rostrally, at the level of the first rhombomere, a thin column of Phox2-expressing cells is found in the lateral wall of the rhombencephalon. Combined Phox 2 immunocytochemistry/DBH in situ hybridization identified these cells as the progenitors of the locus coeruleus and subcoeruleus (Fig. 5A). The rostral-most expression domain of Phox2, at the met-mesencephalic junction, consisted of the two patches of cells, which in sagittal sections appeared as streams of cells leaving the ventral proliferating epithelium just rostral and caudal to the fovea isthmi (Fig. 5B). The signal in these cells became weaker at later stages, precluding their identification.

At E13.5, there was a complex pattern of scattered Phox $2^{+}$cells in the lateral tegmentum of the medulla (not shown). In addition, combined Phox $2 / \mathrm{DBH}$ detection allowed the identification of the coeruleus complex (Fig. 5C,D), the A5 region, and the A1 region (not shown) but not yet the A2 region.

\section{Phox2 expression in the postnatal CNS}

We examined Phox 2 expression in the CNS on P12, when the different nuclei are identifiable by their characteristic shape and location. To identify unambiguously as many Phox2-positive cell groups as possible, we systematically combined anti-Phox 2 immunohistochemistry with in situ hybridization for either DBH or ChAT. We could readily identify all of the known (nor)adrenergic centers of the hindbrain. The most numerous and compact collection of Phox2/DBH double-stained cells was found at the level of the pons, in the lateral floor of the IVth ventricle, corresponding to the locus coeruleus (A6) (Figs. 6A,B, 7C,D), extending dorsally into the alar plate (A4) and connected ventrally at its caudal end to the A5 group by the stream of Phox $2^{+} / \mathrm{DBH}^{+}$cells of the locus subcoeruleus (Fig. $7 B$ ). Groups of strongly $\mathrm{DBH}^{+} /$ Phox $2^{+}$cells were found in a more or less continuous column in the ventrolateral medulla, corresponding caudally to groups A1 and C1 (Kalia et al., 1985a,b) (Figs. 6C, 7G-M), and rostral to the facial nucleus to A5 and A7 (Dahlström and Fuxe, 1964) (Fig. $7 A-E$ ). In the dorsomedial aspect of the caudal medulla and in close proximity to the nucleus tractus solitarius (nTS), we could locate the A2/C2 group (Kalia et al., 1985a,b) (Fig. $7 H-L$ ). The area postrema, known to contain noradrenergic neurons as part of the A2 region (Kalia et al., 1985b), also contained many weakly Phox2- and DBH-positive cells, but the weak signals made it difficult to distinguish between singly and doubly labeled cells (not shown).

Four groups of $\mathrm{Phox}^{+}$cells were also stained by the ChAT probe and could be identified as (1) some cells in the nucleus ambiguus (nA) (Figs. $6 D, 7 H, I$ ), sometimes occupying the entire nucleus, sometimes restricted to its ventrolateral aspect depending on the rostrocaudal level; (2) many motoneurons of the dorsal nucleus of the vagus nerve (dmnX) (Figs. $6 E$, $7 H-L)$; (3) part $(\sim 50 \%)$ of the motoneurons of the facial nucleus (nVII) (Figs. $6 F, 7 C-G$ ); and (4) the efferent vestibular nucleus (Figs. $6 A, B, 7 D$ ). Strikingly, all of the cells of the latter were found to coexpress DBH (Fig. 6A) and ChAT (Fig. 6B). All other motor nuclei of cranial nerves were Phox2-negative, although we could not rule out that the two patches of positive cells across the isthmic boundary seen at earlier stages (E11.5) and much more faintly later were the anlagen of the trochlear and occulomotor nuclei.

Many Phox $2^{+}$cells expressing neither ChAT nor DBH were found in the medulla, i.e., a group of cells in the nTS (Figs. $6 E$, $7 H-L)$, which was in continuity with more dispersed cells spanning the lateral-most field of the reticular formation and extending ventrally to the region of the $\mathrm{nA}$ and the facial nucleus (Fig. $7 G-L)$. It is in this area that preganglionic neurons projecting to the salivary and lacrymal glands are found (Contreras et al., 1980); however, although weakly ChAT positive cells were found scattered throughout this area, few were found to express Phox2. Other groups of unidentified Phox2-expressing neurons were found in the spinal cord, where they formed continuous columns along the entire length of the spinal cord: a central group in area $\mathrm{X}$, just dorsal to the central canal, and two lateral groups at the border between the dorsal horn and the dorsolateral funiculus (Fig. $7 N$ ), just dorsal to the sympathetic preganglionic neurons, which are $\mathrm{ChAT}^{+} / \mathrm{Phox}^{-}$(not shown).

\section{DISCUSSION}

Two striking correlates emerge from the Phox 2 expression pattern, which we discuss below.

\section{Phox2 and transmitter phenotype}

Phox 2 is expressed in virtually all neurons known to use noradrenaline or adrenaline as neurotransmitter and that can be identified by their expression of $\mathrm{DBH}$ : sympathetic postganglionic neurons and all of the (nor)adrenergic centers of the hindbrain, including the ventrolateral group $(\mathrm{A} 1 / \mathrm{C} 1, \mathrm{~A} 5$, and $\mathrm{A} 7)$, the dorsomedial group (A2/C2), and the coeruleus complex (locus coeruleus, locus subcoeruleus, and A4). The correlation between DBH and Phox2 expression extends beyond classic (nor)adrenergic sites to include cells that have been reported to transiently express $\mathrm{DBH}$ (Grzanna and Coyle, 1978; Jonakait et al., 1984; Landis et al., 

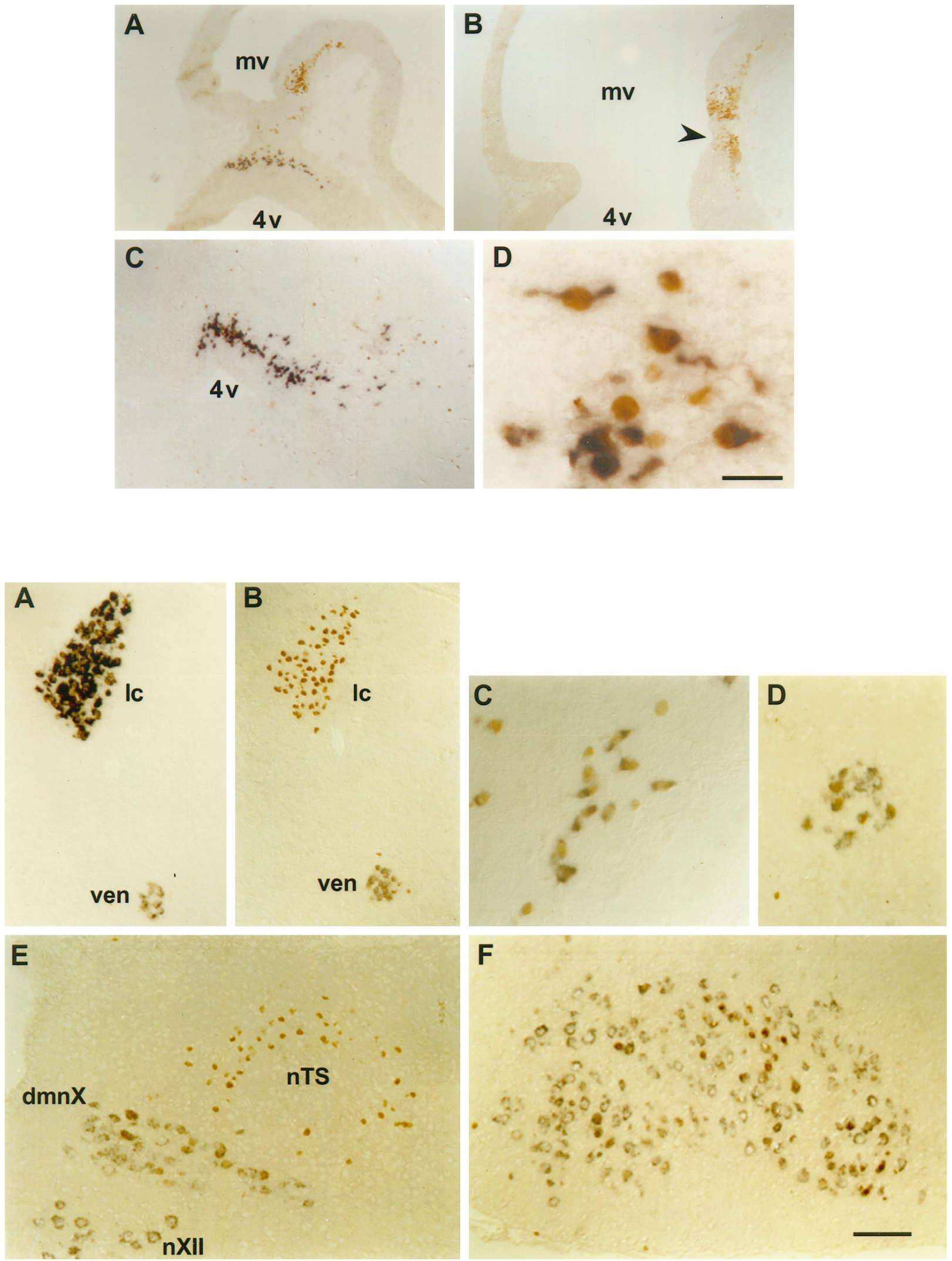
1987) or that we identified as such: postganglionic neurons of the enteric and parasympathetic system until E13 and, even more transiently, the distal VIIth, IXth, and Xth cranial ganglia. At all sites, Phox 2 expression either precedes or is concomitant with DBH expression and either continues together with it into postnatal stages (in sympathetic ganglia and (nor)adrenergic centers) or outlasts it (in cranial, myenteric, and parasympathetic ganglia). The relative timing of Phox 2 and $\mathrm{DBH}$ expression in the peripheral nervous system is summarized in Figure 8.

Finally, Phox 2 is expressed in the vestibular efferent nucleus, which is classically considered to be cholinergic, but which we found to contain both DBH and ChAT (see below). Hence, Phox2 is present at virtually all sites that permanently or transiently express DBH, the only possible exception being some neurons in the area postrema.

Other sites of Phox 2 expression correlate with the cholinergic phenotype, notably in the facial nucleus, the nA, and the dmnX. Although this correlation is partial, we cannot exclude the possibility that Phox 2 could participate in the determination of the cholinergic phenotype in these cells. An interesting feature of some cholinergic sites of Phox 2 expression is that they point to a possible ontogenic relatedness of the adrenergic and cholinergic phenotypes. Indeed, several cholinergic Phox $2^{+}$neurons are in close association with (nor)adrenergic ones (e.g., the A2/C2 group and the $\mathrm{dmnX}$, or the $\mathrm{C} 1$ group and $\mathrm{nVII}$ ), and others coexpress $\mathrm{DBH}$, either transiently (e.g., parasympathetic postganglionic neurons) or permanently (e.g., the vestibular efferent nucleus). In line with a possible coexistence or interconvertibility of the two phenotypes, a bona fide switch from a noradrenergic to a cholinergic phenotype has been documented in the postganglionic sympathetic neurons innervating the sweat gland (Patterson and Chun, 1977; Schotzinger and Landis, 1988) and in the sympathetic trunk of LIF transgenic mice (Bamber et al., 1994), and a reverse switch has been documented in transplanted cholinergic neurons (Coulombe and Bronner-Fraser, 1986). Also, noradrenergic and cholinergic properties have been colocalized in cultured sympathetic neurons (Barbu et al., 1992) and in some neurons in the dmnX (Manier et al., 1987).

Finally, other Phox2-positive cells are clearly neither cholinergic nor (nor)adrenergic, like the chemically unidentified neurons of the nTS, the lateral reticular formation, and the spinal cord.
Therefore, although its expression pattern exceeds that of $\mathrm{DBH}$, Phox 2 is a strong candidate for regulating aspects of the (nor)adrenergic phenotype, perhaps DBH itself. In line with this, a high-affinity binding site for Phox 2 has been found in a functional module of the human DBH promoter (Tissier-Seta et al., 1993), and a slight transactivating effect of rat Phox2 has been observed on the rat $\mathrm{DBH}$ promoter in cultured cells (Zellmer et al., 1995).

\section{Phox2 and the autonomic control pathways}

Another striking functional correlate of the Phox 2 expression pattern emerged from this study: many Phox2-positive sites are involved in the medullospinal reflex control of autonomic functions.

Phox 2 is expressed in the three cranial ganglia whose primary sensory neurons relay visceral sensations relevant to autonomic functions. The VIIth ganglion carries the taste stimuli of the anterior two thirds of the tongue, the distal IXth ganglion relays taste and visceral sensations from the posterior third of the tongue as well as baro-, chemo-, and osmoreception from the carotid body, and the distal Xth ganglion innervates the taste buds of the epiglottis and conveys visceral sensations from the pharynx, the larynx, and the thoracic and abdominal viscera. All of these afferents converge mainly on relay sensory neurons in the nTS (Ciriello, 1983; Loewy, 1990) and area postrema (Kalia and Sullivan, 1982), where Phox $2^{+}$cells were found. The efferent branch of medullospinal autonomic reflexes is also composed mainly of Phox2-positive neurons: preganglionic neurons of the parasympathetic system (certainly the dmnX, possibly the subpopulation of $\mathrm{Phox}^{+}$cells in the $\mathrm{nA}$ and dorsal to the $\mathrm{nVII}$ ), postganglionic neurons of the parasympathetic and sympathetic systems, and the myenteric plexus of the enteric nervous system. In addition, Phox 2 is expressed in the (nor)adrenergic centers of the hindbrain among which, most notably, $\mathrm{C} 1, \mathrm{~A} 5$, and $\mathrm{A} 7$ are thought to be relay centers of autonomic reflexes, establishing connections, sometimes reciprocal, with the nTS and the sympathetic and parasympathetic preganglionic neurons (Loewy et al., 1979; Ross et al., 1984, and references therein; Loewy, 1990). The locus coeruleus has only minor descending projections and is thought to relay visceral sensations to more rostral levels of the neuraxis. Finally, some of the unidentified Phox $2^{+}$neurons in the lateral tegmental field occupy the same arc-like reticular region where interneurons that project to cardiac vagal motoneurons have been found (Standish et al., 1995).

\section{$\leftarrow$}

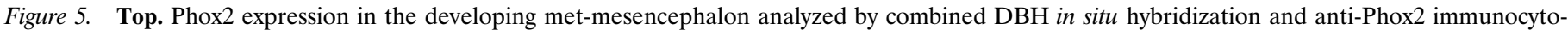

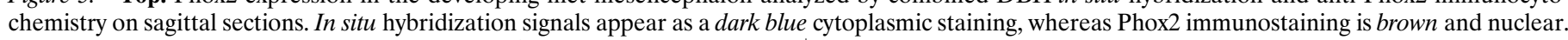

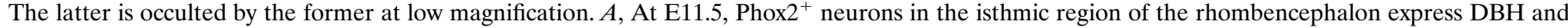

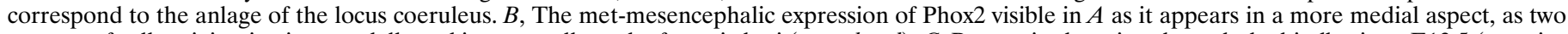

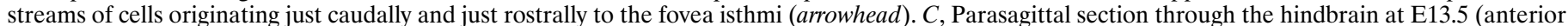



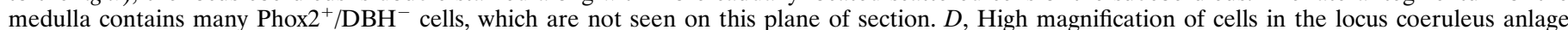

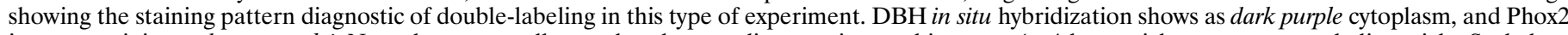

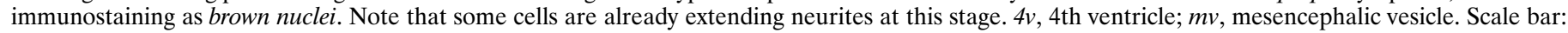
$A, 320 \mu \mathrm{m} ; B, 230 \mu \mathrm{m} ; C, 175 \mu \mathrm{m} ; D, 24 \mu \mathrm{m}$.

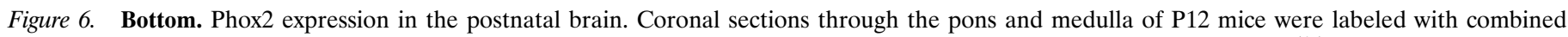

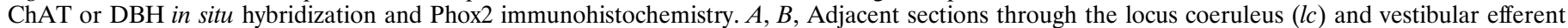

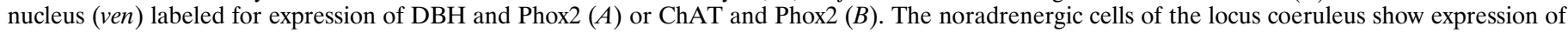

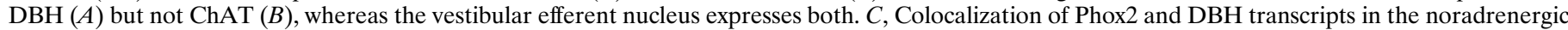

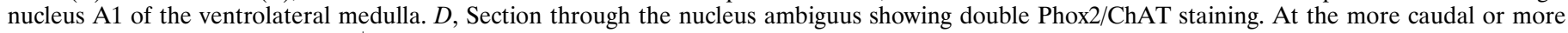

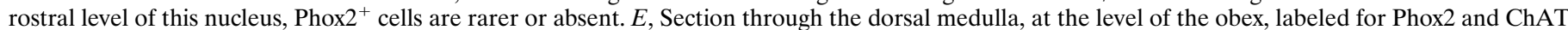

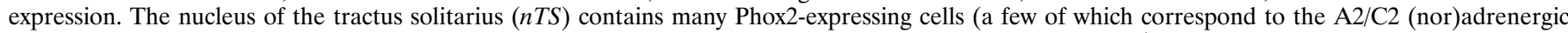

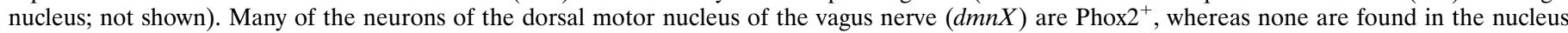

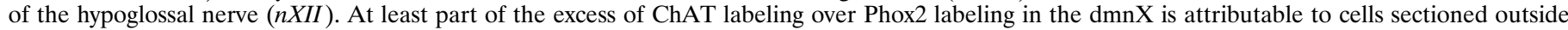

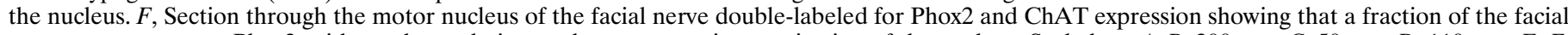

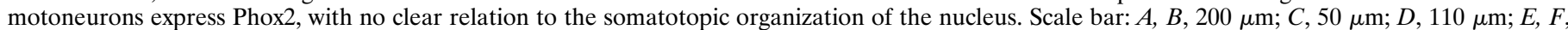
$160 \mu \mathrm{m}$. 
A

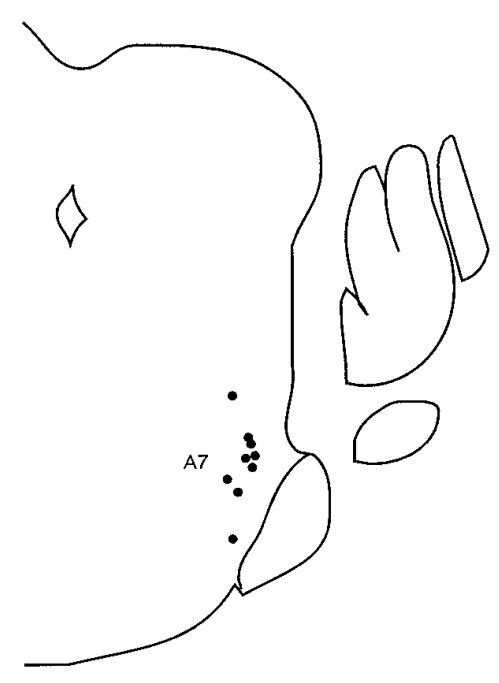

B

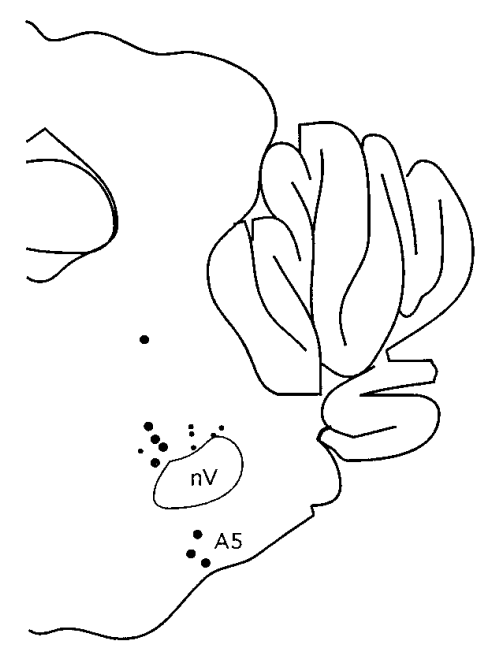

C

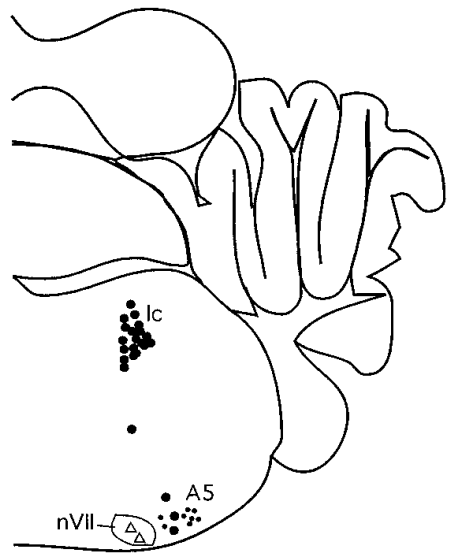

D

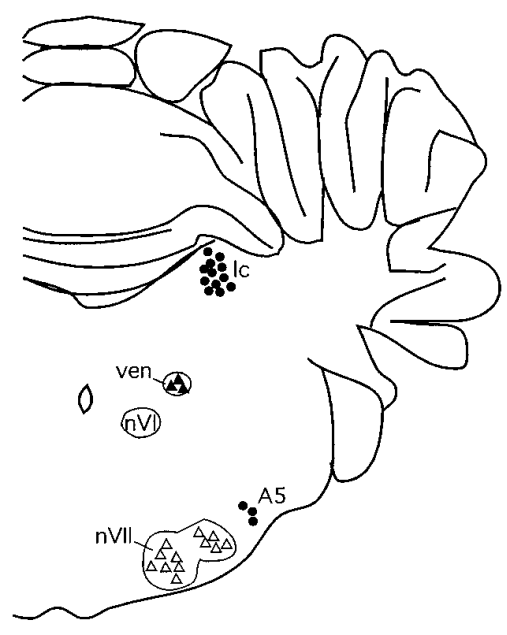

$\mathrm{E}$

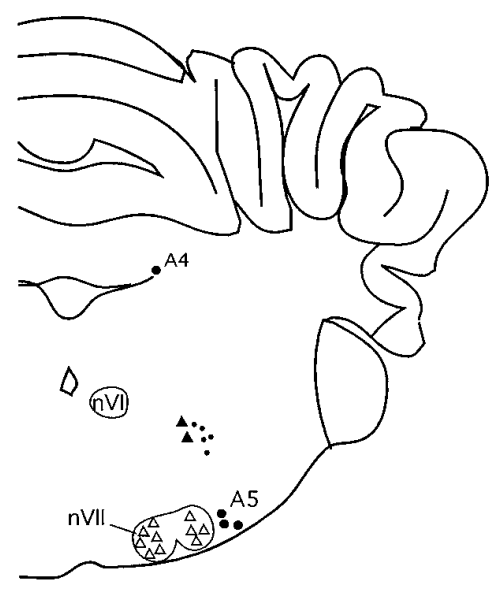

$\mathrm{F}$

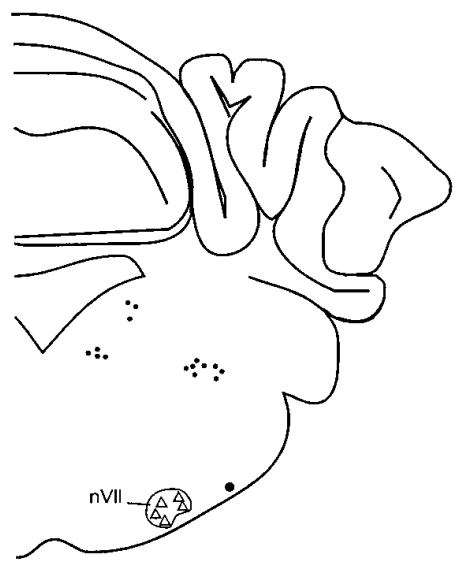

Figure 7. Schematic representation of the distribution of Phox2-expressing neurons on coronal sections of postnatal mouse brain $(A-M)$ and a transversal section through the spinal cord $(N)$. The levels relative to the obex are $(A)+2.1 \mathrm{~mm},(B)+1.8 \mathrm{~mm},(C)+1.5 \mathrm{~mm},(D)+1.3 \mathrm{~mm},(E)+1.2 \mathrm{~mm},(F)+1.1$ $\mathrm{mm},(G)+0.9 \mathrm{~mm},(H)+0.6 \mathrm{~mm},(I)+0.4 \mathrm{~mm},(J)+0.2 \mathrm{~mm},(K)-0.1 \mathrm{~mm},(L)-0.3 \mathrm{~mm}$, and $(M)-0.6 \mathrm{~mm}$. Each symbol represents one to two Phox2-positive neurons: large dots, cells coexpressing Phox2 and DBH; open triangles, cells coexpressing Phox2 and ChAT; black triangles, cells coexpressing Phox2, ChAT, and DBH; and small dots, cells expressing Phox2 but neither DBH nor ChAT. Figure and legend continue. 

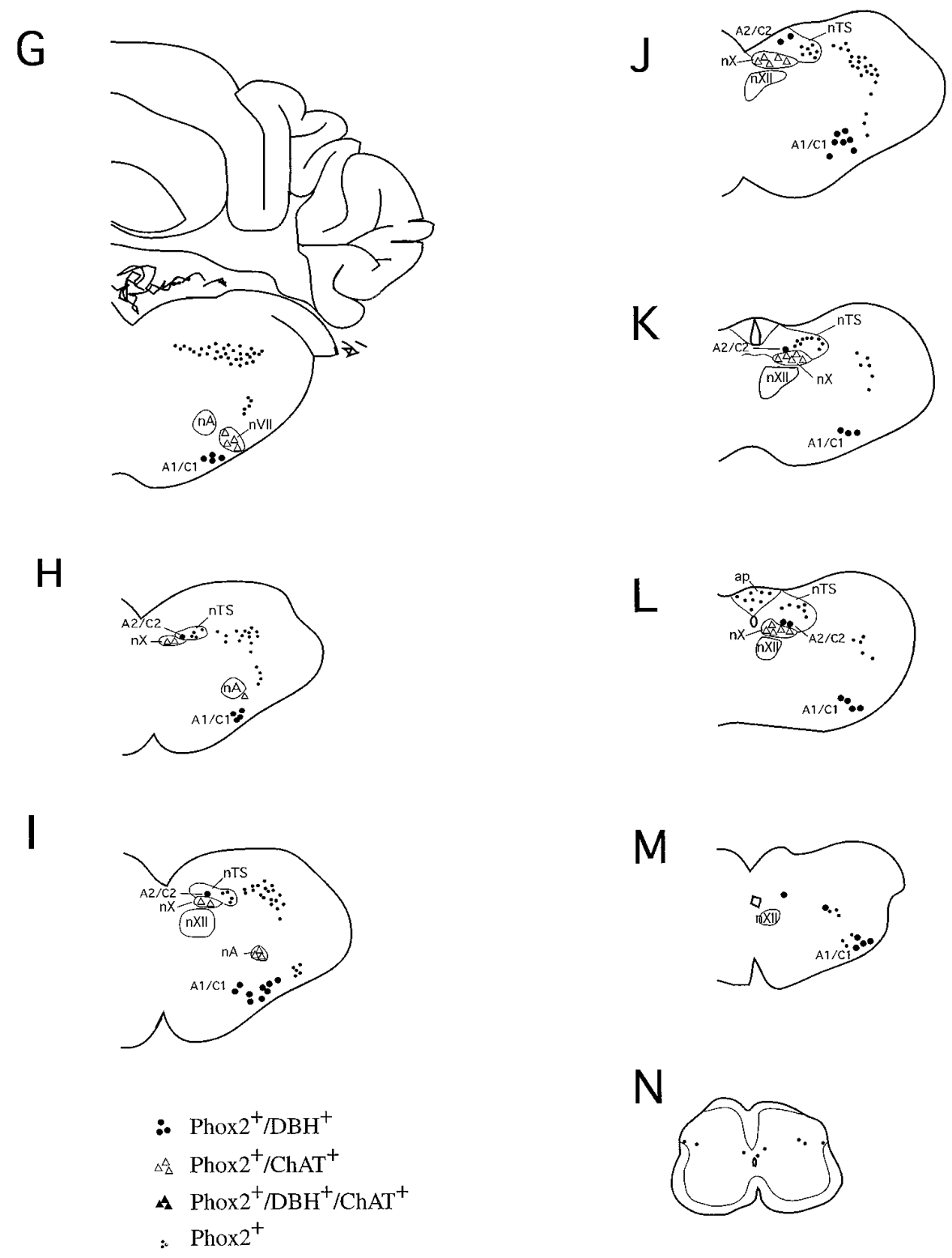

Figure 7 continued.

No attempt was made to distinguish noradrenergic from adrenergic cells; therefore the ventrolateral and dorsomedial (nor)adrenergic groups are designated $\mathrm{A} 1 / \mathrm{C} 1$ and $\mathrm{A} 2 / \mathrm{C} 2$, respectively, throughout their caudorostral extent. A1, A2, A4, A5, and A7, noradrenergic nuclei A1, A2, A4, A5, and A7, respectively. ap, Area postrema; $C 1, C 2$, adrenergic groups $\mathrm{C} 1$ and $\mathrm{C} 2$; $l c$, locus coeruleus; $n V$, motor nucleus of the trigeminal (cranial Vth) nerve; $n V I$, nucleus of the abducens (cranial VIth) nerve; $n V I I$, motor nucleus of the facial (cranial VIIth) nerve; dmnX, dorsal motor nucleus of the vagus nerve; $n X I I$, nucleus of the hypoglossal nerve; $n A$, nucleus ambiguus; $n T S$, nucleus of the tractus solitarius; ven, vestibular efferent nucleus.

Therefore, many $\mathrm{Phox}^{+}$neurons are involved in, or are located in areas involved in, the medullospinal level of autonomic control. The only clear or likely exceptions include the subpopulation of motoneurons in the facial nucleus, the vestibular efferent nucleus, and the spinal cord neurons. It is noteworthy, however, that interneurons located in the dorsal horn and area X, where Phox $2^{+}$cells are found, have been implicated in the sympathetic outflow (Strack et al., 1989; Loewy, 1990).

Hence, most of the four to six relay stations that have been proposed to make up the medullary control circuits of cardiovascular functions (Guyenet, 1990; Spyer, 1990), for example, are either Phox $2^{+}$(IXth and Xth ganglia, C1, postganglionic sympathetic and parasympathetic ganglia), or they comprise areas where many $\mathrm{Phox}^{+}$cells are found (nTS, nA, laterov- entral medulla), the only clear exception being the preganglionic sympathetic neurons. Several groups of $\mathrm{Phox} 2^{+}$cells are synaptically connected. For example, Phox $2^{+}$neurons of the dmnX project to $\mathrm{Phox} 2^{+}$postganglionic parasympathetic neurons. On the other hand, they receive input from $\mathrm{Phox}^{+}$ sensory neurons of the Xth ganglion (Kalia and Sullivan, 1982) and from the Phox $2^{+}$A5 adrenergic group (Loewy et al., 1979), although the possibility of indirect connections through local interneurons has not been formally excluded.

\section{Possible significance of the neurophysiological correlate of Phox2 expression}

The presence of such large fractions of Phox2-expressing neurons at different levels of well defined neuronal circuits can hardly be 


\section{$\begin{array}{lllllll}\text { E9.5 } & \text { E10.5 } & \text { E11.5 } & \text { E12.5 } & \text { E13.5 } & \text { E16.5 } & \text { P0 }\end{array}$}

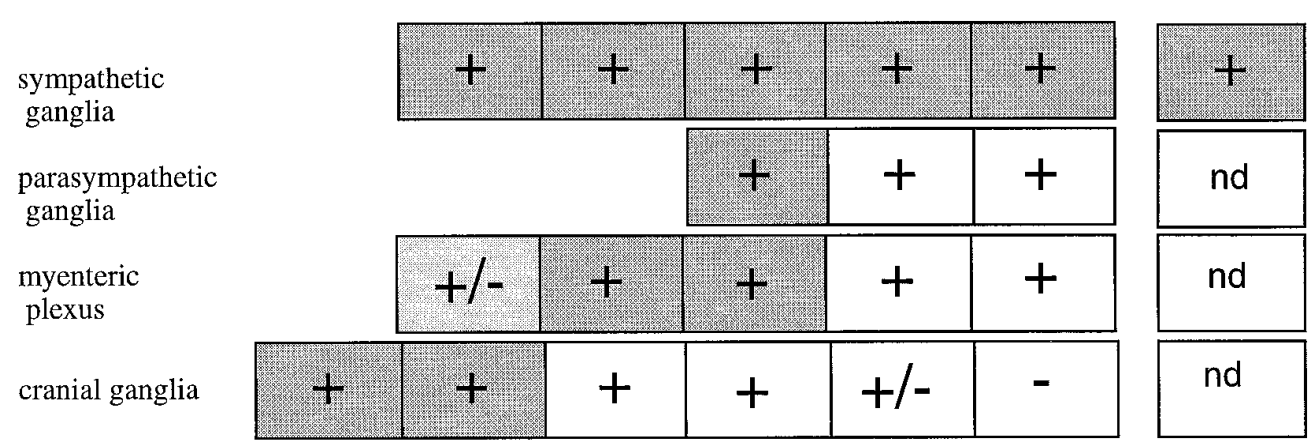

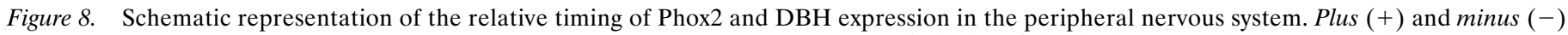

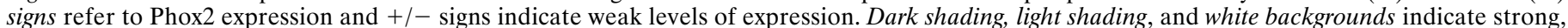

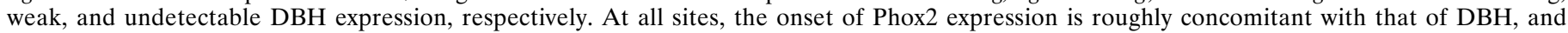

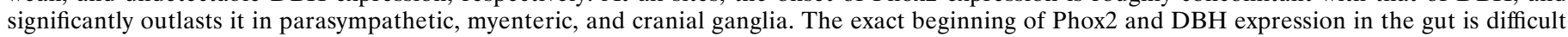

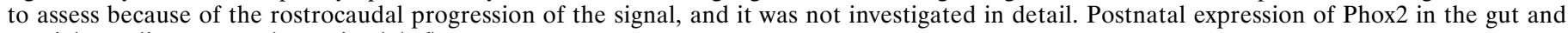
cranial ganglia was not determined ( $n d)$.

coincidental, nor can it be a consequence of the establishment of these circuits, because it clearly precedes it in sympathetic ganglia and cranial sensory ganglia, which we have shown to express Phox 2 at the time (sympathetic ganglia) or even before (cranial ganglia) they form and well before axonal outgrowth. In CNS neurons, Phox 2 protein can be detected as soon as they become postmitotic, thus possibly concomitant with neurite extension, but before synaptogenesis. Therefore, it is tempting to speculate that Phox2 expression in interconnected neuronal groups is causal to this interconnection. Strikingly, DRG11, a close structural relative of Phox2, recently has been reported to be expressed in dorsal root ganglia neurons and some of their synaptic targets in the dorsal horn of the spinal cord (Saito et al., 1995), a situation reminiscent of Phox 2 expression in cranial ganglia and the nTS.

How could a transcription factor promote integration into the same synaptic circuit of two distant neurons in which it is expressed? The most parsimonious models would have Phox 2 acting through the same target gene(s) in the two neurons. A first model would propose that it regulates the expression of molecules involved in pathfinding at a distance. For example, Phox 2 could control the expression of the receptor for a neurite outgrowthpromoting substance secreted in the target territory, which would promote directional axonal outgrowth from the distant presynaptic cell and nondirectional dendritic growth in its local postsynaptic partner.

Rather than being involved in pathfinding at a distance, Phox2 could be involved in target selection by controlling the expression of cell-cell adhesion receptors in the two interacting cells. Again, the most parsimonious hypothesis would invoke the same adhesion molecule on both cells. This leads to the very simple model in which target cell recognition involves a homophilic adhesion molecule whose expression is controlled by the same transcription factor in the two synaptic partners. Precedents for expression of the same adhesion molecule by both axons and their postsynaptic partners can be found in the literature. During chick brain development, for instance, strong expression of the two homophilic adhesion molecules $\mathrm{N}$ - and $\mathrm{R}$-cadherin is restricted to two different tectofugal pathways and to the nuclei with which they connect (Redies et al., 1993). Another example is provided by limbic system-associated membrane protein (LAMP), expressed by functionally interconnected cortical and subcortical neurons of the limbic system (Keller et al., 1989; Pimenta et al., 1995). Antibody perturbation experiments suggest that LAMP is essential for proper targeting of the hippocampal mossy fiber projection (Pimenta et al., 1995). The immunoglobulin-like cell adhesion molecule BEN, capable of homophilic binding, was found on inferior olivary axons and their cerebellar targets (Chédotal et al., 1996). In Drosophila, the homophilic adhesion molecule connectin is found both on a subset of muscles and on motoneuron axons that innervate them (Nose et al., 1992). Another phenomenology that could involve homophilic interactions between Phox2-expressing cells is axonal fasciculation. Indeed, virtually all peripheral and central Phox $2^{+}$neurons that connect the hindbrain to the periphery have axons coursing through the VIIth, IXth, and Xth nerves, regardless of their final destination or physiological role.

Finally, the ongoing postnatal expression of Phox2, like that of other homeodomain proteins (Thor et al., 1991; Simeone et al., 1994; Alvarez-Bolado et al., 1995), raises the possibility that it is involved in the physiology or the plasticity of the neural circuits in which it is expressed.

In summary, the distinct patterns of Phox2 expression during neuro-ontogeny are consistent with Phox 2 playing a role in two important aspects of neuronal identity: neurotransmitter phenotype and the molecular recognition between groups of functionally connected neurons. Ongoing studies are aimed at experimentally verifying the roles we postulate by in vivo manipulation of Phox2 expression.

\section{REFERENCES}

Alvarez-Bolado G, Rosenfeld MG, Swanson LW (1995) Model of forebrain regionalization based on spatio temporal patterns of POU-III homeobox gene expression, birthdates, and morphological features. J Comp Neurol 355:237-295.

Baetge G, Pintar JE, Gershon MD (1990) Transiently catecholaminergic (TC) cells in the bowel of the fetal rat: precursors of noncatecholaminergic enteric neurons. Dev Biol 141:353-380.

Bamber BA, Masters BA, Hoyle GW, Brinster RL, Palmiter RD (1994) Leukemia inhibitory factor induces neurotransmitter switching in transgenic mice. Proc Natl Acad Sci USA 91:7839-7843.

Barbu M, Pourquie O, Vaigot P, Gateau G, Smith J (1992) Phenotypic plasticity of avian embryonic sympathetic neurons grown in a chemically defined medium: direct evidence for noradrenergic and cholinergic properties in the same neurons. J Neurosci Res 32:350-362.

Bodmer R, Barbel S, Sheperd S, Jack JW, Jan LY, Jan YN (1987) Transformation of sensory organs by mutations of the cut locus of $D$. melanogaster. Cell 51:293-307. 
Chédotal A, Pourquié O, Ezan F, San Clemente H, Sotelo C (1996) BEN as a presumptive target recognition molecule during the development of the olivocerebellar system. J Neurosci 16:3296-3310.

Ciriello J (1983) Brainstem projections of aortic baroreceptor afferent fibers in the rat. Neurosci Lett 36:37-42.

Cochard P, Goldstein M, Black IB (1979) Initial development of the noradrenergic phenotype in autonomic neuroblasts of the rat embryo in vivo. Dev Biol 71:100-114.

Contreras RJ, Gomez MM, Norgren R (1980) Central origins of cranial nerve parasympathetic neurons in the rat. J Comp Neurol 190:373-394.

Coulombe JN, Bronner-Fraser ME (1986) Cholinergic neurons acquire adrenergic neurotransmitters when transplanted into an embryo. Nature 324:569-572.

Dahlström A, Fuxe K (1964) Evidence for the existence of monoaminecontaining neurons in the central nervous system. I. Demonstration of monoamines in the cell bodies of brain stem neurons. Acta Physiol Scand [Suppl 62] 232:1-55.

D'Amico-Martel A, Noden DM (1983) Contributions of placodal and neural crest cells to avian cranial peripheral ganglia. Am J Anat 166:445-468.

Ericson J, Thor S, Edlund T, Jessell TM, Yamada T (1992) Early stages of motor neuron differentiation revealed by expression of homeobox gene Islet-1. Science 256:1555-1560.

Erkman L, McEvilly RJ, Luo L, Ryan A, Hooshmand F, O'Connell SM, Keithley EM, Rapaport DH, Ryan AF, Rosenfeld MG (1996) Role of transcription factors Brn-3.1 and Brn-3.2 in auditory and visual system development. Nature 381:603-606.

Ernsberger U, Patzke H, Tissier-Seta J-P, Reh T, Goridis C, Rohrer H (1995) The expression of tyrosine hydroxylase and the transcription factors cPhox-2 and Cash-1: evidence for distinct inductive steps in the differentiation of chick sympathetic precursor cells. Mech Dev 52:125-136.

Frantz GD, Weimann JM, Levin ME, McConnell SK (1994) Otx1 and Otx2 define layers and regions in the developing cerebral cortex and cerebellum. J Neurosci 14:5725-5740.

Ghysen A, Dambly-Chaudière C (1993) The specification of sensory neuron identity in Drosophila. BioEssays 15:293-298.

Groves AK, George KM, Tissier-Seta J-P, Engel JD, Brunet J-F, Anderson DJ (1995) Differential regulation of transcription factor gene expression and phenotypic markers in developing sympathetic neurons. Development 121:887-901.

Grzanna R, Coyle JT (1978) Dopamine- $\beta$-hydroxylase in rat submandibular ganglion cells which lack norepinephrine. Brain Res 151:206-214

Guillemot F, Lo L-C, Johnson JE, Auerbach A, Anderson DJ, Joyner AL (1993) Mammalian achaete-scute homolog 1 is required for the early development of olfactory and autonomic neurons. Cell 75:463-476.

Guyenet PG (1990) Role of the ventral medulla oblongata in blood pressure regulation. In: Central regulation of autonomic functions (Loewy AD, Spyer KM, eds), pp 145-167. Oxford: Oxford UP.

Jin Y, Hoskins R, Horvitz HR (1994) Control of type-D GABAergic neuron differentiation by $C$. elegans UNC-30 homeodomain protein. Nature 372:780-783.

Jonakait GM, Markey KA, Goldstein M, Black IB (1984) Transient expression of selected catecholaminergic traits in cranial sensory and dorsal root ganglia of the embryonic rat. Dev Biol 101:51-60.

Kalia M, Sullivan JM (1982) Brainstem projections of sensory and motor components of the vagus nerve in the rat. J Comp Neurol 211:248-264.

Kalia M, Fuxe K, Goldstein M (1985a) Rat medulla oblongata. III. Adrenergic ( $\mathrm{C} 1$ and $\mathrm{C} 2)$ neurons, nerve fibers and presumptive terminal processes. J Comp Neurol 233:333-349.

Kalia M, Fuxe K, Goldstein M (1985b) Rat medulla oblongata. II. Dopaminergic, noradrenergic (A1 and A2) and adrenergic neurons: nerve fibers, and presumptive terminal processes. J Comp Neurol 233:308-332.

Keller F, Rimvall K, Barbe MF, Levitt P (1989) A membrane glycoprotein associated with the limbic system mediates the formation of the septo-hippocampal pathway in vitro. Neuron 3:551-561.

Landis SC, Jackson PC, Fredieu JR, Thibault J (1987) Catecholaminergic properties of cholinergic neurons and synapses in adult rat ciliary ganglion. J Neurosci 7:3574-3587.
Loewy AD (1990) Central autonomic pathways. In: Central regulation of autonomic functions (Loewy AD, Spyer KM, eds), pp 88-103. Oxford: Oxford UP.

Loewy AD, McKellar S, Saper CB (1979) Direct projections from the A5 catecholamine cell group to the intermediolateral cell column. Brain Res 174:309-314.

Manier M, Mouchet P, Feuerstein C (1987) Immunohistochemical evidence for the coexistence of cholinergic and catecholaminergic phenotypes in neurons of the vagal motor nucleus in the adult rat. Neurosci Lett 80:141-146.

Marìn F, Puelles L (1995) Morphological fate of rhombomeres in quail/ chick chimeras: a segmental analysis of hindbrain nuclei. Eur J Neurosci 7:1714-1738

Miller III DM, Niemeyer CJ (1995) Expression of the unc-4 homeoprotein in Caenorhabditis elegans motor neurons specifies presynaptic input. Development 121:2877-2886.

Nakai S, Kawano H, Yudate T, Nishi M, Kuno J, Nagata A, Jishage K-I, Hamada H, Fujii H, Kawamura K, Shiba K, Noda T (1995) The POU domain transcription factor Brn-2 is required for the determination of specific neuronal lineages in the hypothalamus of the mouse. Genes Dev 9:3109-3121.

Nose A, Mahajan VB, Goodman CS (1992) Connectin: a homophilic cell adhesion molecule expressed on a subset of muscles and the motoneurons that innervate them in Drosophila. Cell 70:553-567.

Patterson PH, Chun LLY (1977) The induction of acetylcholine synthesis in primary cultures of dissociated rat sympathetic neurons. Dev Biol $56: 263-280$.

Pfaff SL, Mendelsohn M, Stewart CL, Edlund T, Jessell TM (1996) Requirement for LIM homeobox gene Isl1 in motor neuron generation reveals a motor neuron-dependent step in interneuron differentiation. Cell 84:309-320.

Pimenta AF, Zhukareva V, Barbe MF, Reinoso BS, Grimley C, Henzel W, Fischer I, Levitt P (1995) The limbic system-associated membrane protein is an Ig superfamily member that mediates selective neuronal growth and axon targeting. Neuron 15:287-297.

Redies C, Engelhart K, Takeichi M (1993) Differential expression of Nand R-cadherin in functional neuronal systems and other structures of the developing chicken brain. J Comp Neurol 333:398-416.

Ross CA, Ruggiero DA, Joh TH, Park DH, Reis DJ (1984) Rostral ventrolateral medulla: selective projections to the thoracic autonomic cell column from the region containing $\mathrm{C} 1$ adrenaline neurons. J Comp Neurol 228:168-185.

Saito T, Greenwood A, Sun Q, Anderson DJ (1995) Identification by differential RT-PCR of a novel paired homeodomain protein specifically expressed in sensory neurons and a subset of their CNS targets. Mol Cell Neurosci 6:280-292.

Shaeren-Wiemers N, Gerfin-Moser A (1993) A single protocol to detect transcripts of various types and expression levels in neural tissue and cultured cells: in situ hybridization using digoxigenin-labelled cRNA probes. Histochemistry 100:431-440.

Schoneman MD, Ryan A, McEvilly RJ, O'Connell SM, Arias CA, Kalla KA, Li P, Sawchenko PE, Rosenfeld MG (1995) Development and survival of the endocrine hypothalamus and posterior pituitary gland requires the neuronal POU domain factor Brn-2. Genes Dev 9:3122-3135.

Schotzinger RJ, Landis SC (1988) Cholinergic phenotype developed by noradrenergic sympathetic neurons after innervation of a novel cholinergic target in vivo. Nature 335:637-639.

Simeone A, D'Apice MR, Nigro V, Casanova J, Graziani F, Acampora D, Avantaggiato V (1994) Orthopedia, a novel homeobox-containing gene expressed in the developing CNS of both mouse and Drosophila. Neuron 13:83-101.

Spyer KM (1990) The central nervous organization of reflex circulatory control. In: Central regulation of autonomic functions (Loewy AD, Spyer KM, eds), pp 168-188. Oxford: Oxford UP.

Standish A, Enquist LW, Escardo JA, Schwaber JS (1995) Central neuronal circuit innervating the heart defined by transneuronal transport of pseudorabies virus. J Neurosci 15:1998-2012.

Sternberg PW, Liu K, Chamberlin HM (1992) Specification of neuronal identity in Caenorhabditis elegans. In: Determinants of neuronal identity (Shankland M, Macagno ER, eds), pp 1-43. San Diego: Academic.

Strack AM, Sawyer WB, Hughes JH, Platt KB, Loewy AD (1989) A general pattern of CNS innervation of the sympathetic outflow demon- 
strated by transneuronal pseudorabies viral infection. Brain Res 491:156-162.

Tetsuya K, Satoshi I, Shin-Ichi H, Eiji T, Hiroshi A, Masaki S, Yasufumi E, Kaoru S (1991) Identification of a different-type homeobox gene, BarH1, possibly causing Bar (B) and Om(1D) mutations in Drosophila. Proc Natl Acad Sci USA 88:4343-4347.

Thor S, Ericson J, Brännström T, Edlund T (1991) The homeodomain LIM protein Isl-1 is expressed in subsets of neurons and endocrine cells in the adult rat. Neuron 7:881-889.

Tissier-Seta J-P, Hirsch M-R, Valarché I, Brunet J-F, Goridis C (1993) A possible link between cell adhesion receptors, homeodomain proteins and neuronal identity. C R Acad Sci [III] 316:1305-1315.

Tsuchida T, Ensini M, Morton SB, Baldassare M, Edlund T, Jessell TM, Pfaff SL (1994) Topographic organization of embryonic motor neurons defined by expression of LIM homeobox genes. Cell 79:957-970.
Valarché I, Tissier-Seta J-P, Hirsch M-R, Martinez S, Goridis C, Brunet J-F (1993) The mouse homeodomain protein Phox2 regulates Ncam promoter activity in concert with Cux/CDP and is a putative determinant of neurotransmitter phenotype. Development 119:881-896.

Walthall WW, Plunkett JA (1995) Genetic transformation of the synaptic pattern of a motoneuron class in Caenorhabditis elegans. J Neurosci 15:1035-1043.

Wilkinson DG (1992) Whole mount in situ hybridization of vertebrate embryos. In: In situ hybridization. A practical approach (Wilkinson DG, ed), pp 75-83. Oxford: Oxford UP.

Zellmer E, Zhang Z, Greco D, Rhodes J, Cassel S, Lewis EJ (1995) A homeodomain protein selectively expressed in noradrenergic tissue regulates transcription of neurotransmitter biosynthetic genes. J Neurosci 15:8109-8120. 